\title{
mau \\ Nematodes in the Pine Forests of Northern and Central Greece
}

Maria Karmezi ${ }^{1,2, *}$, Alkmini Bataka ${ }^{1}$, Dimitrios Papachristos ${ }^{3}$ (D) and Dimitrios N. Avtzis ${ }^{1}$ (D)

1 Forest Research Institute, Hellenic Agricultural Organization Demeter, Vassilika, 57006 Thessaloniki, Greece; alkminimp@fri.gr (A.B.); dimitrios.avtzis@fri.gr (D.N.A.)

2 Zoology Department, School of Biology, Faculty of Sciences, Aristotle University of Thessaloniki, 54124 Thessaloniki, Greece

3 Scientific Directorate of Entomology and Agricultural Zoology, Benaki Phytopathological Institute, Kifissia, 14561 Athens, Greece; d.papachristos@bpi.gr

* Correspondence: mkarmezi@bio.auth.gr

check for updates

Citation: Karmezi, M.; Bataka, A.; Papachristos, D.; Avtzis, D.N. Nematodes in the Pine Forests of Northern and Central Greece. Insects 2022, 13, 194. https://doi.org/ $10.3390 /$ insects13020194

Academic Editors: Brian T. Forschler and Natsumi Kanzaki

Received: 13 December 2021 Accepted: 11 February 2022 Published: 13 February 2022

Publisher's Note: MDPI stays neutral with regard to jurisdictional claims in published maps and institutional affiliations.

Copyright: (c) 2022 by the authors Licensee MDPI, Basel, Switzerland. This article is an open access article distributed under the terms and conditions of the Creative Commons Attribution (CC BY) license (https:// creativecommons.org/licenses/by/ $4.0 /)$.
Simple Summary: Pine wood nematode Bursaphelenchus xylophilus is the agent of pine wilt disease and one of the most important forest tree pathogens worldwide, transmitted through beetles of the Monochamus genus. As an invasive species, it has spread beyond its natural range by human activity mainly wood trade. The devastating impact it has on pine forests has led to severe environmental and economic damages in its introduced countries. The wide distribution of Monochamus spp. beetles in many parts of the world along with favourable climatic conditions, which are both important factors for the establishment of pine wilt disease, have raised awareness over its continuous expansion. Therefore, in an attempt to control and even inhibit its further spread and consequently its severely adverse impacts, appropriate measures have already been taken and implemented from countries across the globe.

\begin{abstract}
In the context of plants or plant products protection by harmful organisms, measures have been taken by EU countries in order to prevent their introduction and establishment into the EU, and also limit their expansion in case they do enter. Such a case is Bursaphelenchus xylophilus (Parasitaphelenchidae, Nematoda), already recorded in Portugal and Spain. So, Member States should take all the appropriate steps in order to monitor and confine if necessary susceptible plants and/or plant products. Such measures include annual surveys even in countries where pine wilt disease does not occur yet. Therefore, national survey programs are widely established, sampling and examining samples from pine trees showing suspicious symptoms that could potentially be attributed to B. xylophilus. In this direction, such a network has also been established in Greece collecting and examining wood samples nationwide. In total, 123 wood samples were collected from conifer trees of Northern and Central Greece. Though B. xylophilus was absent from all samples examined, four other Bursaphelenchus species were identified. In addition, other nematode taxa were also recorded, including several phytophagous, microbivorous as well as predatory nematode species. This highlights the fact that besides preventing the introduction of B. xylophilus in Greece, national survey programs can significantly contribute to and enhance our knowledge of the indigenous nematode species.
\end{abstract}

Keywords: Bursaphelenchus spp.; national survey program; nematodes; conifers; Greece

\section{Introduction}

The pine wood nematode (PWN) Bursaphelenchus xylophilus Steiner \& Buhrer 1934 is one of the most important pathogens worldwide [1] that causes pine wilt disease (PWD), and it is currently included in the EPPO A2 list of pests that are recommended for regulation as quarantine pests [2]. B. xylophilus natural pathway of transport between hosts is by the adult stages of the longhorn beetle of the genus Monochamus (Coleoptera, Cerambycidae). B. xylophilus is transmitted either during maturation feeding on healthy trees 
(primary transmission) or during oviposition on weakened and susceptible trees (secondary transmission) [3]. PWN dispersal juveniles ("dauer" larvae) are carried mainly within the respiratory system (tracheae) of Monochamus spp. beetles. During maturation feeding (phytophagous phase), PWN is transmitted on healthy pine trees where it spreads in the vascular system of the tree and resin canals. There it feeds on epithelial cells and living parenchyma causing a rapid reduction in the complete cessation of the resin flow. Cell destruction leads to embolism of the tracheids, blocking water conductance (cavitation) tree's death, or dead trees attract female insects for oviposition and nematodes enter the tree by oviposition slits in the bark (mycophagous phase). Monochamus spp. larvae burrow into the wood where nematodes surround the pupal chambers and enter into the insect's body through openings such as the spiracles. The transmission cycle continues through the maturation feeding of the young immature adult Monochamus insects. [3-5]. However, the high risk of introduction of the pine wood nematode into other countries, revealed in the relevant Pest Risk Analysis [6], is significantly magnified by human-mediated activities, following the routes and pathways employed by international wood trade either as a commodity or as wood packaging material (WPM) [7].

The pine wood nematode is indigenous in North America (the US and Canada) [8] where native pine species are relatively tolerant to its infestation. That was not the case in Japan, however, the first country where B. xylophilus was accidentally introduced at the beginning of the 20th century [9-13]. Japanese pine species were far more susceptible, and B. xylophilus expanded rapidly, resulting in extensive damages with reports of an annual loss rate in timber of 1.0 million $\mathrm{m}^{3}$ in the $70^{\prime} \mathrm{s}$ that peaked at 2.4 million $\mathrm{m}^{3}$ in $1979[14,15]$. Soon afterwards, B. xylophilus had spread to other neighboring Asian countries [16,17] that were confronted with similarly devastating impacts. In China, more than 1.7 million hectares had been affected by PWD until 2008, with more than 53 million trees dying out within a single year [18,19], whereas, in Korea, B. xylophilus is estimated to be causing annual losses of about 8 million US dollars [20] besides any additional costs for pest control and management [21].

In Europe, the pine wood nematode was first recorded in continental Portugal [22], and despite the containment measurements taken immediately [7], it subsequently expanded to Spain [23] and Madeira Island [24]. The estimated mortality risk of pine trees in southern Europe due to PWN is higher than 50\%, something that could possibly have devastating effects on the European forests that occupy about 82 million hectares. The risk of $B$. $x y$ lophilus further spreading in Europe is even higher in areas where its insect vectors are present [25]. By 2030 the cumulative wood loss in the EU has been estimated at $€ 22$ billion representing 3.2\% of the total value of PWN sensitive conifer trees [26].

Given the fact that high temperature and low humidity positively affect the spread and establishment of the PWD [10,27-29], coupled with the increase in international trade and movement of goods, the future impact of PWD is expected to increase [21,26], with Southern EPPO regions, in particular, exhibiting very high risk [30]. Situated at the eastern part of the Mediterranean basin, Greece can be readily included among the countries threatened most by a possible introduction of $B$. xylophilus, particularly as pine forests occupy a large proportion of Greek mainland and islands [31,32], its vector M. galloprovincialis Olivier 1795 is present [3] and Greece's suitable climate conditions [33,34] favour the progress of the disease [35]. In this direction, numerous samples from all over the country are annually examined in the framework of the Greek national survey program against forest quarantine pests, in the attempt to promptly detect the pine wood nematode and inhibit its unimpeded expansion in forest ecosystems. Nevertheless, survey programs can simultaneously increase our basic knowledge on indigenous nematode species occurring in Greek forests as well, something very important given the limited number of studies on indigenous species [36]. Therefore, the purpose of this study is to document the indigenous nematode community that inhabits Greek conifer forests parallel to the Greek national survey program against quarantine pests, in this case, B. xylophilus. 


\section{Materials and Methods}

In the framework of the National Survey Program regarding B. xylophilus, wood disc samples were collected from areas situated in Northern and Central Greece as well as the Northern Aegean islands. Samples were collected from fourteen regional units, namely eleven from Northern Greece (Halkidiki, Drama, Evros, Florina, Pella, Pieria, Rodopi, Serres, Thesprotia, Thessaloniki and Xanthi) two from Central Greece (Aitoloakarnania and Karditsa) and one from Northern Aegean islands (Lesvos). Samples were collected from phytosanitary inspectors during their regular inspections on permanent sites or emergency inspections at sites with weakened and dead trees. Wood disc samples were collected from the trunk at breast height and/or the branches, while at the same the location and the coordinates of each site were recorded. Finally, wood disc samples were sent and examined at the Forest Research Institute in Thessaloniki. In total, one hundred and twenty-three wood samples were collected from dying or diseased conifer trees. Samples were processed immediately after their arrival at the laboratory.

Nematodes were extracted using a modified Baermann funnel technique [37], and each sample contained about 10 gr of wood, cut into small to medium-sized pieces. Wood chips were wrapped in fine mesh and placed inside glass funnels of $100 \mathrm{~mm}$ in diameter. At the end of each funnel, a piece of soft silicone tube was attached to the stem. The tube was closed with a squeezer clip, and the funnel was then filled with water until it entirely covered the wood chips. Funnels were placed on a wooden custom-made stand appropriately designed for the extraction of multiple samples. Wood chips were soaked in water for at least $48 \mathrm{~h}$ at room temperature. The presence of nematodes was detected with the use of a binocular stereoscope (Zeiss SV8, $2 \times$ magnification zoom). Isolated nematodes were picked with a micropipette and mounted on a glass slide for further identification under a microscope (Zeiss Axio Imager A1, $10 \times-100 \times$ magnification).

Nematode identification was based on their morphological characteristics such as the stomodeum, reproductive organs, and tail morphology [8,38-41]. Nematodes were also assigned to trophic groups according to Yeates et al. [42], Scholze \& Sudhaus [43], and Ferris [44]. Nematodes were identified at species level for the genus Bursaphelenchus, and at genus or family level for the rest of the nematodes recovered, while in some cases where deeper taxonomic identification was not possible, they were only classified according to their trophic group. Only nematode occurrence (presence/absence) in each sample was documented.

In order to detect any differences in pine nematode communities between regional units, Cluster analysis was performed based on the identified nematode taxa (species, genera, and families). Nematodes classified only into trophic groups were excluded from the analysis. Unweighted pair-group average (UPGMA) was used as a hierarchical clustering algorithm while distances were estimated using the Dice similarity index. Analysis was performed using PAST 3.0 [45].

Finally, sample distribution was depicted using QGIS Desktop 3.10.12 A Coruña, and the coordinates were projected using the Greek coordinate reference GGRS87. Greek coastline and regional units' shapefiles were obtained from GEODATA.gov.gr (accessed on 10 February 2022) [46].

\section{Results}

Out of the 123 wood disc samples examined (Figure 1), nematodes were detected in 60 samples, i.e., $49 \%$ of the samples. B. xylophilus was not detected in any of the 60 samples, although other Bursaphelenchus spp. were detected in 35\% of them (21 samples). Among those samples, 17 samples contained only one Bursaphelenchus species ( $81 \%$ of the samples), while the rest of the samples contained two Bursaphelenchus species. At the same time, the majority of wood disc samples with nematodes ( $95 \%$ of the samples) contained other nematode taxa together with Bursaphelenchus species. 


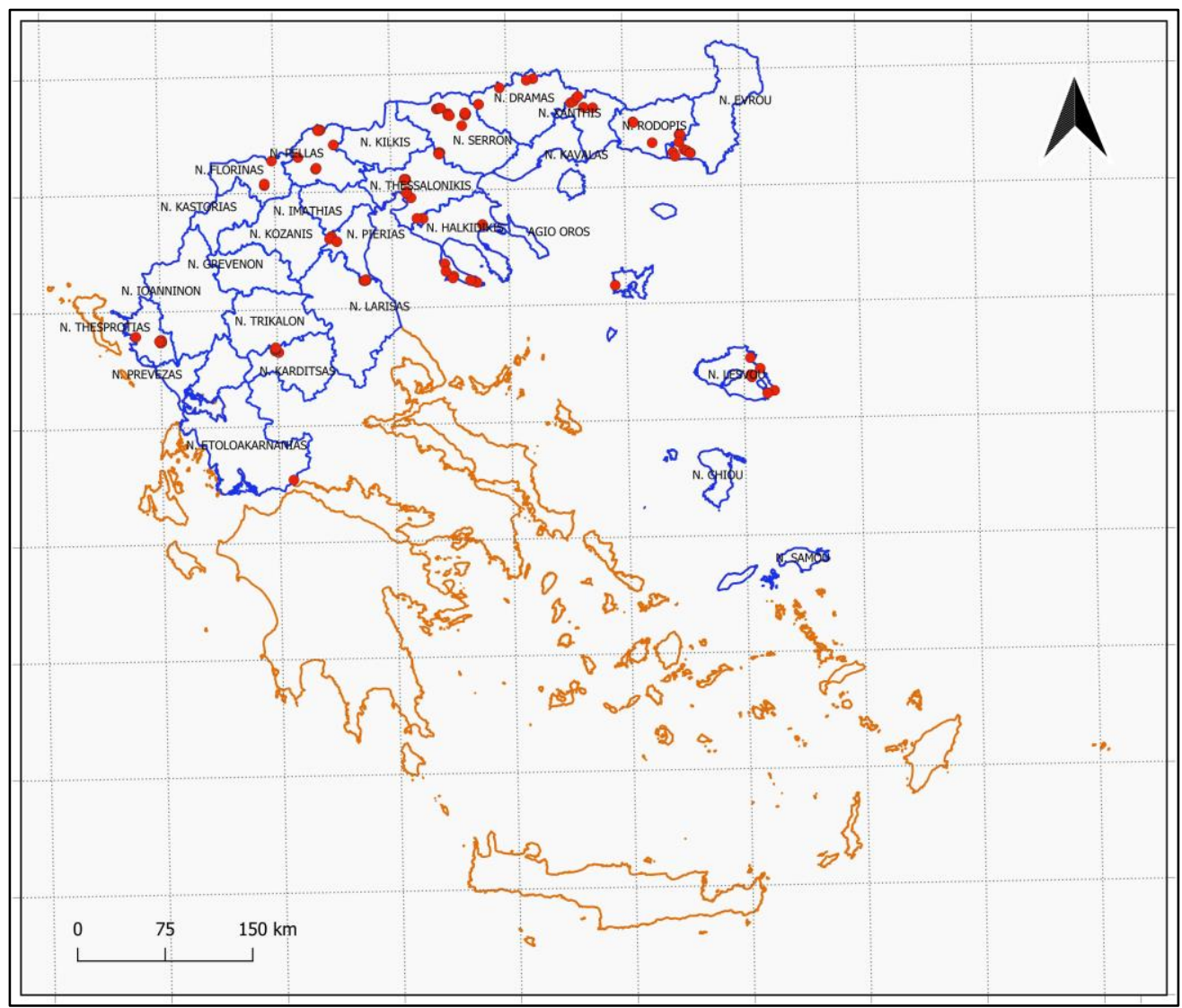

Figure 1. Sample distribution across the sampled areas.

In particular, four Bursaphelenchus species were identified: Bursaphelenchus hellenicus Skarmoutsos, Braasch, Michalopoulou 1998, B. leoni Baujard 1980, B. mucronatus Mamiya and Enda 1979 and B. sexdentati Rühm 1960. In addition to them, there were also some Bursaphelenchus spp. individuals that could not be assigned to a specific species (Table 1) due to either their premature stage and/or the condition of their body. B. hellenicus was the most abundant species followed by B. mucronatus and B. sexdentati with equal frequency, B. leoni was the least encountered species.

Regarding the other nematode taxa detected in the wood disc samples (Table 1), they can also be categorized into trophic groups as follows: Aphelenchoides sp., Aphelenchus sp., Tylencholaimellus sp. (fungivores), Diplenteron sp., Eucephalobus sp., Panagrobelus sp., Panagrolaimus sp., Plectus sp., Pristionchus sp., Rhabditis sp., Rhodolaimus sp. (bacterivores), Devibursaphelenchus sp., Ektaphelenchus sp., Clarkus sp. (predators), Thonus sp. (predator/omnivore) and Parasitorhabditis sp. (entomophilic). Laimaphelenchus sp. is classified in more than one feeding group as it includes non-parasitic plant feeding, fungivorous as well as predatory nematodes. Similarly, although Devibursaphelenchus sp. is classified as fungivorous by Ferris [44], it has also been reported predating on other nematodes [47,48]. Some individuals were identified to family level e.g., Anguinidae (fungivores/plant feeders), Tylenchidae (non-parasitic plant feeders), Dolichodoridae (plant parasitic), and Rhabditidae (bacterivores), while some others were separated only after their feeding group based on the structures of the mouthparts.

Nematodes were detected in the wood of the following conifer species: Abies borisiiregis Mattfeld, P. brutia Tenore, P. halepensis Miller, P. maritima Aito, P. nigra Arnold, and P. sylvestris Linnaeus, as well as unspecified Pinus species (Table 1).

In total, nematodes were detected in overall thirteen out of fourteen regional units, namely Halkidiki, Drama, Evros, Florina, Karditsa, Lesvos, Pella, Pieria, Rodopi, Serres, Thesprotia, Thessaloniki, and Xanthi (Figures 1 and 2). Among them, Thessaloniki and 
Evros were the two regions with the highest number of wood disc samples with nematode presence, and at the same time, these areas exhibited also the highest number of nematode taxa, followed by Halkidiki and Drama (Figure 2). Except for Florina, Pieria, and Serres where no Bursaphelenchus spp. were detected at all, wood disc samples from every other area contained both Bursaphelenchus species and other nematode taxa (Table 1).

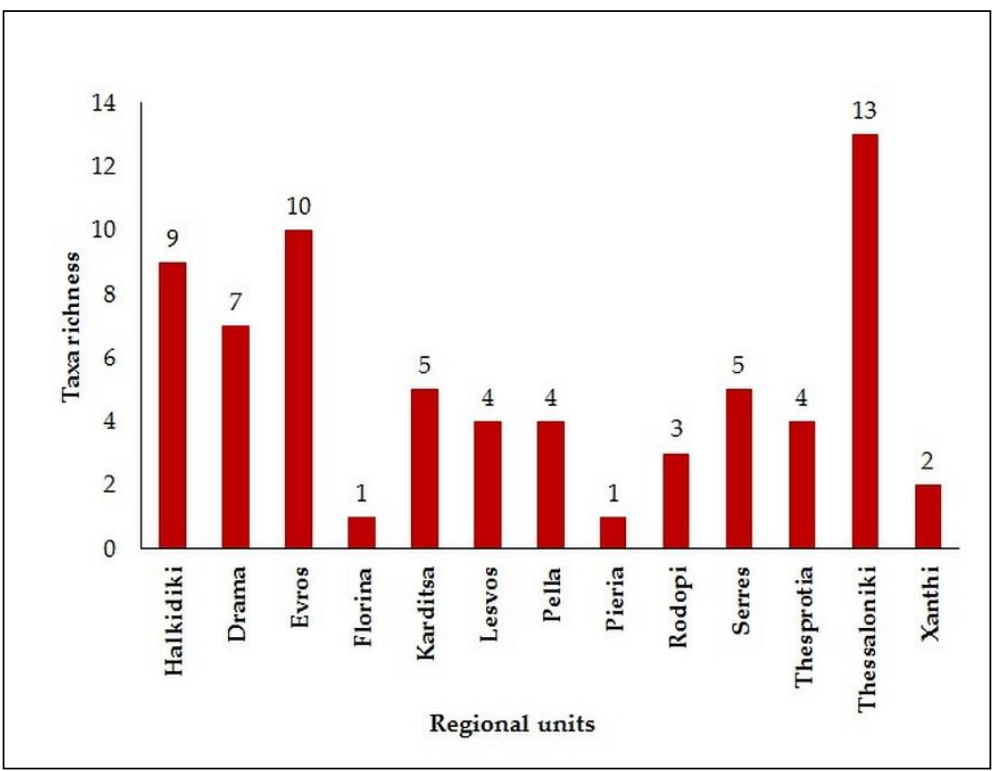

Figure 2. Nematode taxa richness per regional unit.

Cluster analysis based on the occurrence of nematode taxa (Figure 3) resulted in relatively heterogenous clusters with the exception of the marked cluster that includes Drama, Thessaloniki, and Halkidiki. Moreover, Pieria is distinctly separated from all other regions.

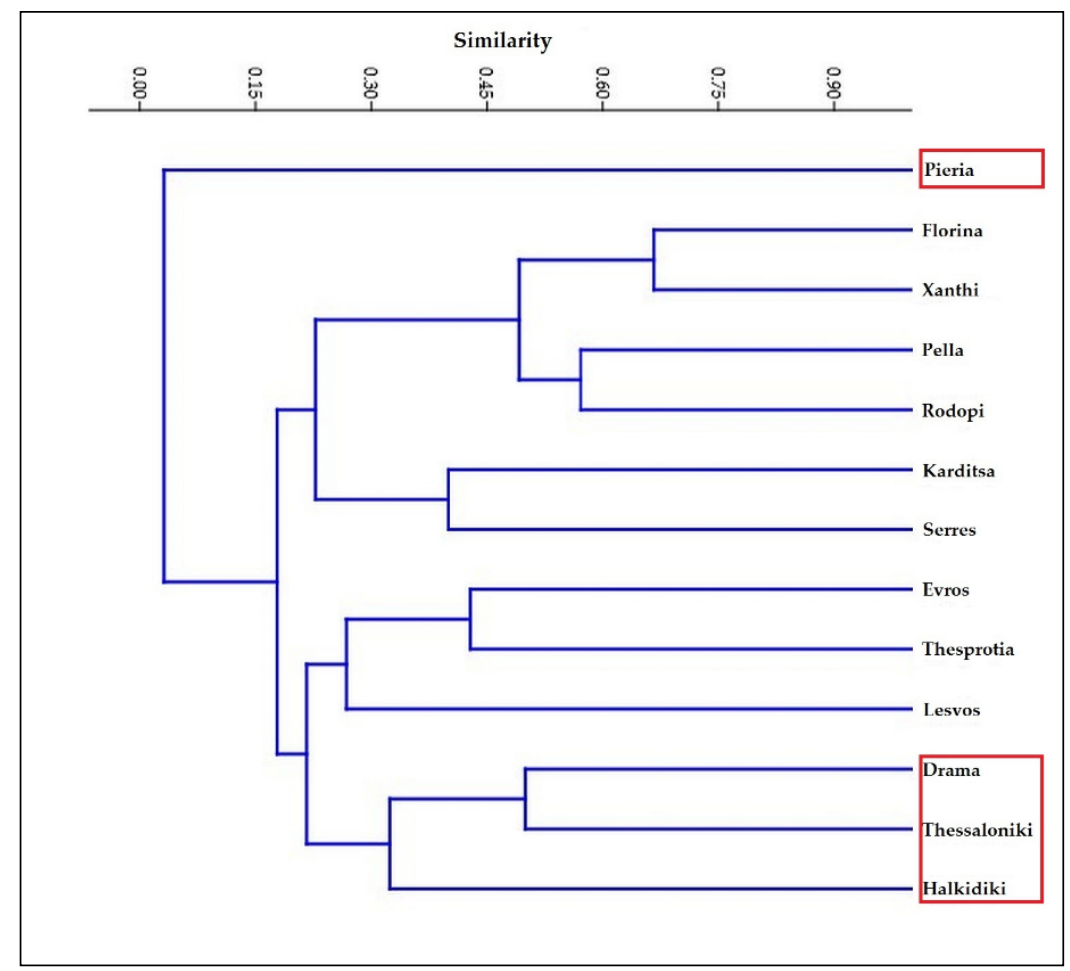

Figure 3. Cluster analysis on nematode taxa. 
Table 1. Tree species, Bursaphelechus spp. and other nematode taxa detected per regional unit and locality.

\begin{tabular}{|c|c|c|c|c|}
\hline Regional Unit & Locality & Tree Species & Bursaphelenchus spp. & Other Nematode spp. \\
\hline Halkidiki & Kassandra & $\begin{array}{l}\text { Pinus halepensis } \\
\text { Pinus halepensis } \\
\text { Pinus halepensis } \\
\text { Pinus halepensis } \\
\text { Pinus halepensis } \\
\text { Pinus halepensis } \\
\text { Pinus halepensis }\end{array}$ & $\begin{array}{c}\text { B. leoni } \\
\text { B. mucronatus }\end{array}$ & $\begin{array}{c}\text { Aphelenchus sp. } \\
\text { Devibursaphelenchus sp. } \\
\text { Diplenteron sp. } \\
\text { Parasitorhabditis sp. } \\
\text { Panagrolaimus sp. } \\
\text { Pristionchus sp. } \\
\text { Thonus sp. }\end{array}$ \\
\hline Drama & $\begin{array}{c}\text { Drama } \\
\text { Neurokopi }\end{array}$ & $\begin{array}{c}\text { Pinus sp. } \\
\text { Pinus sp. } \\
\text { Pinus sp. } \\
\text { Pinus sylvestris } \\
\text { Pinus sylvestris }\end{array}$ & $\begin{array}{l}\text { B. mucronatus } \\
\text { B. hellenicus } \\
\text { B. leoni }\end{array}$ & $\begin{array}{l}\text { Parasitorhabditis sp. } \\
\text { Tylenchidae } \\
\text { Bacterivore } \\
\text { Aphelenchoides sp. } \\
\text { Anguinidae }\end{array}$ \\
\hline Evros & Alexandroupoli & $\begin{array}{l}\text { Pinus brutia } \\
\text { Pinus brutia } \\
\text { Pinus brutia } \\
\text { Pinus brutia } \\
\text { Pinus brutia } \\
\text { Pinus sp. } \\
\text { Pinus sp. } \\
\text { Pinus sp. } \\
\text { Pinus sp. } \\
\text { Pinus sp. }\end{array}$ & $\begin{array}{c}\text { B. hellenicus } \\
\text { Bursaphelenchus sp. }\end{array}$ & $\begin{array}{l}\text { Ektaphelenchus sp. } \\
\text { Panagrolaimus sp. } \\
\text { Parasitorhabditis sp. } \\
\text { Rhabditis sp. } \\
\text { Anguinidae } \\
\text { Clarkus sp. } \\
\text { Eucehpalobus sp. } \\
\text { Laimaphelenchus sp. } \\
\text { Parasitorhabditis sp. } \\
\text { Plant parasitic }\end{array}$ \\
\hline Florina & Florina & Pinus nigra & & Laimaphelenchus sp. \\
\hline Karditsa & Mouzaki & $\begin{array}{l}\text { Pinus brutia } \\
\text { Pinus brutia } \\
\text { Pinus brutia } \\
\text { Pinus brutia }\end{array}$ & Bursaphelenchus sp. & $\begin{array}{c}\text { Aphelenchoides sp. } \\
\text { Rhabditis sp. } \\
\text { Anguinidae } \\
\text { Dolicodoridae }\end{array}$ \\
\hline Lesvos & Lesvos & $\begin{array}{l}\text { Pinus brutia } \\
\text { Pinus brutia }\end{array}$ & $\begin{array}{l}\text { B. hellenicus } \\
\text { B. sexdentati }\end{array}$ & $\begin{array}{l}\text { Eucehpalobus sp. } \\
\text { Plectus sp. }\end{array}$ \\
\hline Pella & $\begin{array}{l}\text { Aridaia } \\
\text { Pella }\end{array}$ & $\begin{array}{c}\text { Abies borisii-regis } \\
\text { Pinus sp. } \\
\text { Pinus sp. } \\
\text { Pinus sylvestris }\end{array}$ & $\begin{array}{c}\text { B. mucronatus } \\
\text { Bursaphelenchus sp. }\end{array}$ & $\begin{array}{l}\text { Aphelenchoides sp. } \\
\text { Laimaphelenchus sp. } \\
\text { Laimaphelenchus sp. }\end{array}$ \\
\hline Pieria & Pieria & Pinus nigra & & Panagrolaimus sp. \\
\hline Rodopi & Rodopi & $\begin{array}{l}\text { Pinus maritima } \\
\text { Pinus maritima }\end{array}$ & $\begin{array}{l}\text { B. hellenicus } \\
\text { B. mucronatus }\end{array}$ & $\begin{array}{l}\text { Laimaphelenchus sp. } \\
\text { Bacterivore }\end{array}$ \\
\hline Serres & Sidirokastro & $\begin{array}{l}\text { Pinus brutia } \\
\text { Pinus brutia } \\
\text { Pinus brutia } \\
\text { Pinus brutia } \\
\text { Pinus brutia }\end{array}$ & & $\begin{array}{l}\text { Laimaphelenchus sp. } \\
\text { Merlinius sp. } \\
\text { Anguinidae } \\
\text { Dolichodoridae } \\
\text { Rhabditidae }\end{array}$ \\
\hline Thesprotia & Thesprotia & $\begin{array}{l}\text { Pinus sp. } \\
\text { Pinus sp. }\end{array}$ & $\begin{array}{c}\text { B. hellenicus } \\
\text { Bursaphelenchus sp. }\end{array}$ & $\begin{array}{c}\text { Clarkus sp. } \\
\text { Tylencholaimellus sp. }\end{array}$ \\
\hline
\end{tabular}


Table 1. Cont.

\begin{tabular}{|c|c|c|c|c|}
\hline Regional Unit & Locality & Tree Species & Bursaphelenchus spp. & Other Nematode spp. \\
\hline \multirow[t]{11}{*}{ Thessaloniki } & Lagkadas & Pinus sp. & Bursaphelenchus sp. & Laimaphelenchus sp. \\
\hline & & Pinus sp. & & Parasitorhabditis sp. \\
\hline & & Pinus sp. & & Rhodolaimus sp. \\
\hline & Thessaloniki & Pinus maritima & B. sexdentati & Aphelenchus sp. \\
\hline & & Pinus maritima & & Laimaphelenchus sp. \\
\hline & & Pinus maritima & & Panagrobelus sp. \\
\hline & & Pinus maritima & & Plectus sp. \\
\hline & & Pinus sp. & B. hellenicus & Aphelenchoides sp. \\
\hline & & Pinus sp. & B. leoni & Merlinius sp. \\
\hline & & Pinus sp. & B. sexdentati & Parasitorhabditis sp. \\
\hline & & Pinus sp. & Bursaphelenchus sp. & Anguinidae \\
\hline \multirow[t]{2}{*}{ Xanthi } & Xanthi & Pinus sylvestris & Bursaphelenchus sp. & Laimaphelenchus sp. \\
\hline & & Pinus sylvestris & & Bacterivore \\
\hline
\end{tabular}

\section{Discussion}

In the current study, nematodes and their communities in pine forests were systematically examined and recorded for the first time in Greece, enhancing significantly our basic knowledge of the indigenous nematode fauna. The study was conducted alongside the annual survey programme against harmful organisms, in this case, B. xylophilus. B. xylophilus was not detected in any of the wood samples examined. In general, the introduction of PWN in Greece through natural dispersal is not very likely since Monochamus spp. beetles, PWN insect vector, cover relatively short distances [3,49]. This fact, however, does not significantly reduce the risk of PWN invading Greece, as international trade and transport of wood products is considered to be the main pathway of B. xylophilus invasion and expansion [50,51], especially when B. xylophilus and its vector are introduced together [51]. In spite of the attempts to ensure proper treatment or monitoring of wood products, materials infested with B. xylophilus and/or its insect vector are being regularly recorded worldwide at points of entry, such as ports [52], even from countries known to be PWN-free [4,53]. For example, in Portugal, B. xylophilus presence is consistently recorded in areas around ports that are associated with the trade of goods [4]. Greece's ports as possible entry points for B. xylophilus are among the ones' that require high priority surveillance in order to prevent a rapid invasion of $B$. xylophilus and pine wilt disease across Europe [54].

Greece, like many other EPPO countries, is considered a risk area for the introduction and establishment of B. xylophilus, given the abundance of its host trees coupled with the occurrence of its insect vector [6]. Out of the seven indigenous Pinus spp. in Greece [31] four are susceptible to PWD: P. halepensis, P. nigra, P. pinea Linnaeus, $P$. sylvestris. In fact, B. xylophilus can be found in almost any conifer species (except Thuja and Taxus spp.) weakened enough to allow Monochamus species to oviposit and transmit the nematode in addition to pine species that express pine wilt disease [55].

Additionally, climatic conditions in Greece further favour a possible establishment of B. $x y$ lophilus. Average summer temperatures in the Mediterranean regions are high enough to support pine wilt disease in susceptible trees [56]. In Greece, the lowest minimum summer temperature is $20^{\circ} \mathrm{C}$ [57], ideal for the development of both B. xylophilus and Monochamus spp. and consequently the expression of pine wilt disease. Both the nematode and its insect vector strongly depend on temperature. In fungal cultures of Botrytis cinerea Persoon (1794), the postembryonic development of B. xylophilus requires $12,6,4-5$, and 3 days at $0{ }^{\circ} \mathrm{C}, 15^{\circ} \mathrm{C}, 21{ }^{\circ} \mathrm{C}, 26^{\circ} \mathrm{C}$, and $30{ }^{\circ} \mathrm{C}$, respectively [58], while it reproduces in 12 days at $15{ }^{\circ} \mathrm{C}, 6$ days at $20^{\circ} \mathrm{C}$ and 3 days at $30{ }^{\circ} \mathrm{C}$ [56]. M. galloprovincialis larval development is also dependent on temperature. There is a linear relationship between temperature and development duration in days between $15^{\circ} \mathrm{C}$ and $30{ }^{\circ} \mathrm{C}$ [59]. However, the developmental rate seems to decrease above $30^{\circ} \mathrm{C}$ for both PWN and pine sawyer 
beetles [56,59], although areas with climatic conditions that do not favour the expression of the disease could possibly act as reservoirs. [6,50].

The natural dispersal of B. xylophilus between host trees occurs primarily during the maturation feeding of Monochamus (Coleoptera, Cerambycidae) species. Even though the main vector of PWN in Europe is M. galloprovincialis [60], and this species occurs widely yet in low population levels in Greece [61], there is always the risk of accidentally introducing non-native sawyer beetles [62,63]. Besides M. galloprovinciallis in Europe and M. carolinensis Olivier 1792 in North America or M. alternatus Hope 1842 in East Asia, many other Monochamus species have been reported capable of carrying B. xylophilus $[3,49,64]$. The remarkable biological similarities among Monochamus species globally, render many of these species putative vectors of B. xylophilus, particularly in the presence of their host trees [49]. Even though it is still not clear whether Monochamus species can directly cause tree mortality, infestation by the pine sawyer beetle is definitely weakening tree physiology, making it more susceptible to other secondary pests and diseases that ultimately lead to significant timber degradation and economic losses $[3,51,65,66]$.

Moreover, besides Monochamus species as vectors of $B$. xylophilus, $\mathrm{PWN}$ has been found in association with other Coleoptera species such as Acanthocinus griseus Fabricius 1793, A. gundaiensis Kano 1933, Amniscus sexguttatus Dillon 1956, Arhopalus rusticus Linnaeus 1758, Aromia bungii Faldermann 1835, Asemum striatum Linnaeus 1758, Corymbia succedanea Hua 2002, Neacanthocinus obsoletus Olivier 1795, N. pusilus Kirby 1837, Spondylis buprestoides Linnaeus, 1758, Uraecha bimaculata Thomson 1864, Xylotrechus sagittatus Germar 1821, Hylobius pales Herbst 1797, Odontotermes formosanus Shiraki 1909, Pissodes approximates Hopkins 1911, Tomicus piniperda Linnaeus 1758, as well as other genera (e.g., Acalolepta sp., Chrysobothris sp., Rhagium sp.). However, there is still no evidence that any of these species can act as vectors of the nematode in nature $[3,56,67]$.

Even though B. xylophilus was not identified among the nematode species retrieved from the wood disc samples, four Bursaphelenchus spp., B. hellenicus, B. leoni, B. mucronatus, and $B$. sexdentati, were detected in about half of the samples with nematode presence indicating a strong occurrence of this genus in pines. B. hellenicus, B. mucronatus, B. leoni, and B. sexdentati, as well as B. eggersi Rühm 1956 and B. vallesianus Braasch, Schönfeld, Polomski, Burgermeister 2004 have already been documented in Greece [32,68,69]. However, B. eggersi [32] a member of the eggersi group [38,40,41,70] and B. vallesianus [69], a member of the sexdentati group $[38,40,41,70]$, were not detected in the present study. In general, B. mucronatus and B. sexdentati are acknowledged as the most abundant species in Europe, with the latter being more frequent in the southern European regions [70,71]. In contrast, $B$. leoni is recognized as a typical Mediterranean species, based on their dispersal and frequency, although they have also been occasionally found in Central Europe [68]. Finally, B. hellenicus exhibits the most limited natural range, which contains only two other countries, namely Italy [72] and Turkey [73] besides Greece [32,74]. Additionally, in terms of pathogenicity, B. mucronatus, B. vallesianus, and B. sexdentati have been characterized to be highly pathogenic $[36,75,76]$ although such findings have not been confirmed under natural forest stand conditions [77], and the expression of virulence could also be dependent on host susceptibility as shown by Carropo et al. [78]. B. leoni was found to be less pathogenic whereas, B. helleniccus is considered to be non-pathogenic [36,68].

Most of the aforementioned Bursaphelenchus species have also been documented in Greece's neighboring and surrounding countries (Table 2). For example, in addition to B. leoni and B. sexdentati, B. idius Rühm 1956 have also been recovered from weakened trees in Cyprus $[79,80]$. Similarly, B. anamurius Akbulut, Braasch, Baysal, Brandstetter, Burgermeister 2007, B. pinophilus Brzeski, and Baujard 1997 and B. vallesianus are already known to occur in Turkey, besides B. hellenicus, B. mucronatus, and B. sexdentati $[73,81-84]$. On the other hand, species richness of Bursaphelenchus spp. in Italy is considerably higher, with numerous other Bursaphelenchus species (e.g., B. abietinus Braasch and Schmutzenhofer 2000, B. andrassyi Dayi, Calin, Akbulut, Gu, Schröder, Vieira, Braasch 2014, B. eremus Rühm 1956, B. fraudulentus Rühm 1956, B. fungivorous Franklin and Hooper 1962, B. minutus 
Walia, Negi, Bajaj, Kalia 2003 and B. tusciae Ambrogioni and Palmisano 1998) having been identified [72,85-88] besides the ones already known in Greece [72,89], something that needs particular attention given the strong commercial relationships.

Table 2. Bursaphelenchus spp. records in Greece and neighboring countries $(\bullet)$ indicates presence ${ }^{1}$.

\begin{tabular}{|c|c|c|c|c|}
\hline Bursaphelenhus spp. & Cyprus & Greece & Italy & Turkey \\
\hline B. abietinus & & & $\bullet$ & \\
\hline B. anamurius & & & & $\bullet$ \\
\hline B. andrassyi & & & - & \\
\hline B. eremus & & & $\bullet$ & \\
\hline B. fraudulentus & & & $\bullet$ & \\
\hline B. fungivorous & & & $\bullet$ & \\
\hline B. hellenicus & & $\bullet$ & $\bullet$ & $\bullet$ \\
\hline B. idius & $\bullet$ & & & \\
\hline B. leoni & $\bullet$ & $\bullet$ & $\bullet$ & \\
\hline B. minutus & & & $\bullet$ & \\
\hline B. mucronatus & & $\bullet$ & - & \\
\hline B. pinophilus & & & & $\bullet$ \\
\hline B. sexdentati & $\bullet$ & $\bullet$ & $\bullet$ & $\bullet$ \\
\hline B. tusciae & & & $\bullet$ & \\
\hline B. vallesianus & & $\bullet$ & & $\bullet$ \\
\hline
\end{tabular}

${ }^{1}$ For references see text.

As more than one Bursaphelenchus species were found in almost $20 \%$ of the wood disc samples inhabited by nematodes, it can be easily deduced that a single tree can host more than one species at the same time. This is something that has also been reported in the past, with up to four different Bursaphelenchus species co-existing in one tree [70,89]. Furthermore, Penas et al. [90] have verified that one insect vector could possibly carry several Bursaphelenchus species, while one Bursaphelenchus species can have different insect vectors [8,70], suggesting a non-specific relationship between insect vectors and Bursaphelenchus spp. [90]. As a consequence, both these mechanisms could explain and maintain the co-existence of different Bursaphelenchus spp. in a single tree. Several insect species can carry Bursaphelenchus nematodes acting as vectors, mainly longhorn beetles (Cerambycidae), bark beetles (Curculionidae-Scolytinae), and jewel beetles (Buprestidae) [8,70,91,92]. For example, B. mucronatus was found to be associated with Ips sexdentatus Börner 1776, while B. sexdentati was associated with Orthotomicus erosus Wollaston 1857, Acanthocinus aedilis Linnaeus 1758, and Arhopalus rusticus Linnaeus 1758 [93]. On the other hand, insect species are capable of vectoring more than one Bursaphelenchus species, e.g., O. erosus carried three different Bursaphelenchus spp., Hylurgus ligniperda Fabricius 1787 two Bursaphelenchus species and both Tomicus piniperda and I. sexdentatus one Bursaphelenchus species each. [94].

To elucidate further the behavior and occurrence of Bursaphelenchus spp. within a host tree, sampling effort should aim at screening different parts of the same tree. Even though Bursaphelenchus species have been recovered from all parts of the tree, occurrence frequencies can differ [95]. Specifically, Bursaphelenchus spp. have been detected both in the stem and the branches, with numbers greater in the lower part of the stem compared to branches, whereas they have been detected even in the roots $[75,96]$. Similar findings have also been reported for B. xylophilus on several occasions. For instance, it has been shown that B. xylophilus nematodes migrate within infected trees soon after the initial infection or inoculation $[97,98]$. Trunk samples had significantly higher nematode density levels than the branches, as B. xylophilus nematodes moved from the infected branches to the stem after infestation [99-101].

Apart from Bursaphelenchus spp., other nematode taxa were also recovered in many wood disc samples. The retrieved taxa belong to different trophic groups, ranging from bacterivores and fungivores, to phytophagous and predatory nematodes, most of which have never been recovered from wood disc samples in Greece before. Many of the genera 
recorded, apart from Bursaphelenchus spp., belong to families that are typical of environments with nutrient availability (Rhabditidae, Panagrolaimidae) or to families adapted to stress with a wide ecological range (Cephalobidae, Aphelenchidae, Aphelenchoididae, Anguinidae). On the other hand, Mononchidae and Quadsianematidae are more sensitive to disturbance and are commonly present in more stable environments [102]. Nevertheless, the presence of many different groups of nematodes appears feasible given the great variety of available resources as it is suggested by Moll et al. [103].

Many of the free-living nematode taxa recovered in the present study have also been reported to be associated with insects, in addition to their initial trophic group assignment [42,104-106] such as members of the families Aphelenchoididae, Rhabditidae, Neodiplogasteridae, and Panagrolaimidae $[42,95,107]$. O. erosus, H. ligniperda, T. piniperda, and I. sexdentatus, as well as Hylastes linearis Erichson 1836 and Pissodes castaneus De Geer 1775 , have all been found to carry nematodes belonging to different genera of the Aphelenchoididae family or other taxonomic groups. As already mentioned, O. erosus, H. ligniperda, T. piniperda, and I. sexdentatus also carried members of the genus Bursaphelenchus [94]. Therefore, it is not uncommon for many nematode species to co-exist in a single host, as has been demonstrated in previous studies [75,80,83,89,108]. For example, Caroppo et al. [89] recorded the co-occurrence of Rhabditida, Aphelenchida, and Tylenchida nematodes, while Đođ et al. [109] found that saprophytic nematodes such as Rhabditidae, Diplogasteridae, and Cephalobidae were found to be dominant but also co-existing with low density populations of Bursaphelenchus spp. Similarly, numerous other nematode genera were found together with the Bursaphelenchus species recovered from Pinus pinaster Aiton trees in Portugal [100].

In order to investigate whether nematode communities from different areas differ from each other, a Cluster analysis was performed. The analysis was based on all reported taxa i.e., both on Bursaphelenchus spp. and the other documented nematode taxa (genera and families), and resulted in the formation of rather heterogenous groups. One would expect that areas with close proximity to each other would group together as in the case of Drama, Thessaloniki, and Halkidiki (Figure 3), which could mean that there is a great possibility that these areas share similar nematode communities, although this could not be verified at the present time. At present, it seems that the different areas examined are classified based on nematode taxa richness rather than community composition.

Many factors affect both nematode presence and community structure such as tree species, environmental variables, as well as the time of the year that sampling took place. For example, Moll et al. [103] who studied nematode communities from deadwood of 13 different tree species came to the conclusion that nematode composition was strongly related to tree species as well as the presence of other co-occurring biota such as fungi and prokaryotes. As already mentioned, environmental variables play an important role in nematode community composition. For instance, soil nematode communities appear to differ across different latitudes [110] while climate variables such as temperature and precipitation are strongly related to nematode community structure and composition [111,112]. Finally, even the time of sampling during the year could also be an important factor influencing nematode community studies since nematode community composition tends to differ among seasons [113].

Environmental traits such as temperature and humidity, as already mentioned, are factors of essential importance influencing the manifestation of PWD. Nematode infection of a healthy pine tree occurs from early June to late July, coinciding with the period of maturation feeding of adult pine sawyers when high temperature and low humidity promote the progress of PWD [10]. As Ichihara et al. [28] have shown, temperature affects migration patterns of B. xylophilus in the tissues of Pinus thunbergii Parlatore and the expression of PWD. Estimated optimal temperatures that PWD progresses have been reported to range from $25^{\circ} \mathrm{C}$ to $30^{\circ} \mathrm{C}[27,29]$.

Relative to climate, climate change is a great concern regarding B. xylophilus expansion into other countries and continents. As climate changes the distribution of PWN is expected 
to expand along with the expression of the disease. Different global scenarios predict the expansion of PWN risk areas globally even in areas that are currently not suitable for the expression of the disease [114]. For instance, future climatic scenarios predict that by 2030 there will be a significant increase in the distribution of PWD across Europe ranging from $8 \%$ up to $34 \%$ of its total area, or even up to $55 \%$ under even more extreme scenarios [54]. As a result, the predicted changes in habitat suitability for the potential host trees (e.g., Pinus sylvestris) would additionally impair the physiology of these trees, rendering them more susceptible to pests and pathogens. This could ultimately alter the current PWD risk areas into high-risk areas in the near future [114]. In general, it can be easily deduced that as climate change progresses, both the intensity and the expansion of PWD is expected to increase, leading to even greater economic damages [21].

\section{Conclusions}

In summary, it can be easily deduced that in the framework of the national survey programs focusing on B. xylophilus, significant knowledge can be gained and accumulated regarding other Bursaphelenchus and nematode species as well. One-year observations and screening of samples from the northern and central parts of Greece have already resulted in the record of four different indigenous Bursaphelenchus species, coupled with the identification of 24 additional nematode taxa, enhancing significantly our knowledge of the poorly studied nematode species inhabiting pine forests in Greece.

Further future investigation, covering greater parts of Greece, even the whole Greek domain, together with the employment of molecular techniques will provide significant and more complete and accurate information regarding indigenous Bursaphelenchus spp. as well as the rest of the local coniferous nematode fauna.

Author Contributions: Conceptualization, M.K., D.P. and D.N.A.; methodology, A.B., D.P. and D.N.A.; validation, M.K. and D.N.A.; formal analysis, M.K.; investigation, M.K.; resources, A.B.; data curation, M.K.; writing-original draft preparation, M.K.; writing-review and editing, D.P. and D.N.A.; visualization, M.K.; supervision, D.N.A.; project administration, A.B. and D.N.A.; funding acquisition, D.P. All authors have read and agreed to the published version of the manuscript.

Funding: The study was partially funded by the Greek Ministry of Rural Development and Food under the national plant pest surveillance programme.

Institutional Review Board Statement: Not applicable.

Informed Consent Statement: Not applicable.

Data Availability Statement: The data presented in this study are available on request from the corresponding author.

Acknowledgments: Phytosanitary Inspectors of Forest Directorates and Forestry offices for their assistance in the collection and submission of samples.

Conflicts of Interest: The authors declare no conflict of interest.

\section{References}

1. Inácio, M.; Nobrega, F.; Vieira, P.; Bonifacio, L.; Naves, P.; Sousa, E.; Mota, M. First detection of Bursaphelenchus xylophilus associated with Pinus nigra in Portugal and in Europe. For. Pathol. 2015, 45, 235-238. [CrossRef]

2. Back, M. Pine Wilt Disease a Global Threat to Forestry. Plant Pandemic Study 4. 2020 British Society for Plant Pathology. Available online: https://www.bspp.org.uk/ (accessed on 15 June 2021).

3. Naves, P.; Bonifácio, L.; de Sousa, E. The pine wood nematode and its local vectors in the Mediterranean Basin. In Insects and Diseases of Mediterranean Forest Systems; Paine, T., Lieutier, F., Eds.; Springer: Cham, Switzerland, 2016; pp. 329-378. [CrossRef]

4. Mota, M.M.; Futai, K.; Vieira, P. Pine wilt disease and the pinewood nematode, Bursaphelenchus xylophilus. In Integrated Management of Fruit Crops Nematodes; Ciancio, A., Mukerji, K., Eds.; Springer: Dordrecht, The Netherlands, 2009; pp. 253-274. [CrossRef]

5. Vicente, C.; Espada, M.; Vieira, P.; Mota, M. Pine wilt disease: A threat to European forestry. Eur. J. Plant Pathol. 2012, 133, 89-99. [CrossRef]

6. $\quad$ Evans, H.; Kulinich, O.; Magnusson, C.; Robinet, C.; Schroeder, T. Report of a Pest Risk Analysis for Bursaphelenchus xylophilus. 09/15450; EPPO: Paris, France, 2009; pp. 1-17. 
7. Sousa, E.; Naves, P.; Bonifácio, L.; Inácio, L.; Henriques, J.; Evans, H. Survival of Bursaphelenchus xylophilus and Monochamus galloprovincialis in pine branches and wood packaging material. Bull. OEPP/EPPO Bull. 2011, 41, 203-207. [CrossRef]

8. Ryss, A.; Vieira, P.; Mota, M.; Kulinich, O. A synopsis of the genus Bursaphelenchus Fuchs, 1937 (Aphelenchida: Parasitaphelenchidae) with keys to species. Nematology 2005, 7, 393-458. [CrossRef]

9. Nickle, W.; Golden, A.; Mamiya, Y.; Wergin, W. On the taxonomy and morphology of the pine wood nematode, Bursaphelenchus xylophilus (Steiner \& Buhrer 1934) Nickle 1970. J. Nematol. 1981, 13, 385.

10. Mamiya, Y. Pathology of the pine wilt disease caused by Bursaphelenchus xylophilus. Annu. Rev. Phytopathol. 1983, 21, 201-220. [CrossRef]

11. Malek, R.B.; Appleby, J.E. Epidemiology of pine wilt in Illinois. Disease distribution. Plant Dis. 1984, 68, 180-186. [CrossRef]

12. Liebhold, A.M.; MacDonald, W.L.; Bergdahl, D.; Mastro, V.C. Invasion by exotic forest pests: A threat to forest ecosystems. For. Sci. 1995, 41 (Suppl. S1), a0001-z0001. [CrossRef]

13. Zhang, K.; Liu, H.; Sun, J.; Liu, J.; Fei, K.; Zhang, C.; Xu, M.; Sun, J.; Ma, X.; Lai, R. Molecular phylogeny of geographical isolates of Bursaphelenchus xylophilus: Implications on the origin and spread of this species in China and worldwide. J. Nematol. 2008, 40, 127-137.

14. Mamiya, Y. History of pine wilt disease in Japan. J. Nematol. 1988, 20, 219.

15. Futai, K. Pine wilt in Japan: From first incidence to the present. In Pine wilt disease; Zhao, B.G., Futai, K., Sutherland, J.R., Takeuchi, Y., Eds.; Springer: Tokyo, Japan, 2008; pp. 5-12. [CrossRef]

16. Li, G.; Shao, G.; Huo, Y.; Xu, F. Discovery of and preliminary investigations on pine wood nematodes in China. For. Sci. Technol. $1983,7,25-28$

17. Dwinell, L.D. The pinewood nematode: Regulation and mitigation. Annu. Rev. Phytopathol. 1997, 35, 153-166. [CrossRef] [PubMed]

18. Zhao, B.G. Pine wilt disease in China. In Pine Wilt Disease; Zhao, B.G., Futai, K., Sutherland, J.R., Takeuchi, Y., Eds.; Springer: Tokyo, Japan, 2008; pp. 18-25. [CrossRef]

19. Robinet, C.; Roques, A.; Pan, H.; Fang, G.; Ye, J.; Zhang, Y.; Sun, J. Role of human-mediated dispersal in the spread of the pinewood nematode in China. PLoS ONE 2009, 4, e4646. [CrossRef] [PubMed]

20. Shin, S.-C. Pine wilt disease in Korea. In Pine Wilt Disease; Zhao, B.G., Futai, K., Sutherland, J.R., Takeuchi, Y., Eds.; Springer: Tokyo, Japan, 2008; pp. 26-32. [CrossRef]

21. An, H.; Lee, S.; Cho, S.J. The effects of climate change on pine wilt disease in South Korea: Challenges and Prospects. Forests 2019, 10, 486. [CrossRef]

22. Mota, M.M.; Braasch, H.; Bravo, M.A.; Penas, A.C.; Burgermeister, W.; Metge, K.; Sousa, E. First report of Bursaphelenchus xylophilus in Portugal and in Europe. Nematology 1999, 1, 727-734. [CrossRef]

23. Abelleira, A.; Picoaga, A.; Mansilla, J.; Aguin, O. Detection of Bursaphelenchus xylophilus, causal agent of pine wilt disease on Pinus pinaster in Northwestern Spain. Plant Dis. 2011, 95, 776. [CrossRef]

24. Fonseca, L.; Cardoso, J.; Lopes, A.; Pestana, M.; Abreu, F.; Nunes, N.; Mota, M.; Abrantes, I. The pinewood nematode, Bursaphelenchus xylophilus, in Madeira Island. Helminthologia 2012, 49, 96-103. [CrossRef]

25. Tóth, Á.; Elekes, M.; Kiss, J. Monitoring quarantine pine wood nematode, Bursaphelenchus xylophilus in Hungary. Acta Phytopathol. Entomol. Hung. 2012, 47, 55-59. [CrossRef]

26. Soliman, T.; Mourits, M.C.; Van Der Werf, W.; Hengeveld, G.M.; Robinet, C.; Lansink, A.G.O. Framework for modelling economic impacts of invasive species, applied to pine wood nematode in Europe. PLoS ONE 2012, 7, e45505. [CrossRef]

27. Braasch, H. Influence of temperature and water supply on mortality of 3-year-old pines inoculated with Bursaphelenchus xylophilus and B. mucronatus. Nachr. Deut. Pflanzenschutzd. 2000, 52, 244-249.

28. Ichihara, Y.; Fukuda, K.; Suzuki, K. Early symptom development and histological changes associated with migration of Bursaphelenchus xylophilus in seedling tissues of Pinus thunbergii. Plant Dis. 2000, 84, 675-680. [CrossRef] [PubMed]

29. Yamaguchi, R.; Matsunaga, K.; Watanabe, A. Influence of temperature on pine wilt disease progression in Pinus thunbergii seedlings. Eur. J. Plant Pathol. 2020, 156, 581-590. [CrossRef]

30. Hirata, A.; Nakamura, K.; Nakao, K.; Kominami, Y.; Tanaka, N.; Ohashi, H.; Takano, K.T.; Takeuchi, W.; Matsui, T. Potential distribution of pine wilt disease under future climate change scenarios. PLoS ONE 2017, 12, e0182837. [CrossRef] [PubMed]

31. Skordilis, A.; Thanos, C. Comparative ecophysiology of seed germination strategies in the seven pine species naturally growing in Greece. In Basic and Applied Aspects of Seed Biology; Ellis, R.H., Black, M., Murdoch, A.J., Hong, T.D., Eds.; Springer: Dordrecht, The Netherlands, 1997; pp. 623-632. [CrossRef]

32. Skarmoutsos, G.; Skarmoutsou, H. First record of Bursaphelenchus nematodes from pine forests in Greece. Plant Dis. 1999, 83, 879. [CrossRef]

33. Lionello, P.; Malanotte-Rizzoli, P.; Boscolo, R.; Alpert, P.; Artale, V.; Li, L.; Luterbacher, J.; May, W.; Trigo, R.; Tsimplis, M. The Mediterranean climate: An overview of the main characteristics and issues. Dev. Earth Environ. Sci. 2006, 4, 1-26. [CrossRef]

34. Peel, M.C.; Finlayson, B.L.; McMahon, T.A. Updated world map of the Köppen-Geiger climate classification. Hydrol. Earth Syst. Sci. 2007, 11, 1633-1644. [CrossRef]

35. Rutherford, T.; Mamiya, Y.; Webster, J. Nematode-induced pine wilt disease: Factors influencing its occurrence and distribution. For. Sci. 1990, 36, 145-155. [CrossRef] 
36. Skarmoutsos, G.; Michalopoulos-Skarmoutsos, H. Pathogenicity of Bursaphelenchus sexdentati, Bursaphelenchus leoni and Bursaphelenchus hellenicus on European pine seedlings. For. Pathol. 2000, 30, 149-156. [CrossRef]

37. Van Bezooijen, J. Methods and Techniques for Nematology; Wageningen University: Wageningen, The Netherlands, 2006; pp. 19-20.

38. Braasch, H.; Burgermeister, W.; Gu, J. Revised intra-generic grouping of Bursaphelenchus Fuchs, 1937 (Nematoda: Aphelenchoididae). J. Nematode Morphol. Syst. 2009, 12, 65-88.

39. Bongers, T. Identification Key: De Nematoden van Nederland, 2nd ed.; KNNV Bibliotheekuitgave: Utrecht, The Netherland, 1994; Volume 46, 408p.

40. Ryss, A.Y.; Subbotin, S. Coevolution of wood-inhabiting nematodes of the genus Bursaphelenchus Fuchs, 1937 with their insect vectors and plant hosts. Zhurnal Obs. Biol. 2017, 78, 13-42.

41. Kanzaki, N.; Giblin-Davis, R.M. Diversity and plant pathogenicity of Bursaphelenchus and related nematodes in relation to their vector bionomics. Curr. For. Rep. 2018, 4, 85-100. [CrossRef]

42. Yeates, G.W.; Bongers, T.; De Goede, R.G.; Freckman, D.W.; Georgieva, S.S. Feeding habits in soil nematode families and genera-an outline for soil ecologists. J. Nematol. 1993, 25, 315. [PubMed]

43. Scholze, V.; Sudhaus, W. A pictorial key to current genus groups of 'Rhabditidae'. J. Nematode Morphol. Syst. 2011, 14, 105-112.

44. Nemaplex-The "Nematode-Plant Expert Information System" A Virtual Encyclopedia on Soil and Plant Nematodes. Available online: http:/ / nemaplex.ucdavis.edu/ (accessed on 29 December 2021).

45. Hammer, O.; Harper, A.; Ryan, P. PAST: Paleontological statistics software package for education and data analysis. Palaeontol. Electron. 2001, 4, 9 .

46. GEODATA.gov.gr. Available online: www.geodata.gov.gr (accessed on 2 December 2020).

47. Gu, J.; Wang, J.; Zheng, J. Devibursaphelenchus wangi sp. n. (Nematoda: Ektaphelenchinae) feeding on Aphelenchoides sp. Russ. J. Nematol. 2010, 18, 49-57.

48. Aliramaji, F.; Pourjam, E.; Atighi, M.R.; Karegar, A.; Pedram, M. Devibursaphelenchus kheirii sp. n. (Nematoda: Ektaphelenchinae) from Iran with remarks on Devibursaphelenchus Kakuliya, 1967. Nematology 2014, 16, 1069-1078. [CrossRef]

49. Akbulut, S.; Stamps, W. Insect vectors of the pinewood nematode: A review of the biology and ecology of Monochamus species. For. Pathol. 2012, 42, 89-99. [CrossRef]

50. Douma, J.; van der Werf, W.; Hemerik, L.; Magnusson, C.; Robinet, C. Development of a pathway model to assess the exposure of European pine trees to pine wood nematode via the trade of wood. Ecol. Appl. 2017, 27, 769-785. [CrossRef]

51. EPPO Datasheet: Bursaphelenchus xylophilus. Available online: https://gd.eppo.int/taxon/BURSXY/datasheet (accessed on 30 December 2021).

52. Webster, J.; Mota, M. Pine wilt disease: Global issues, trade and economic impact. In Pine Wilt Disease: A Worldwide Threat to Forest Ecosystems, 1st ed.; Mota, M., Vieira, P., Eds.; Springer: Dordrecht, The Netherlands, 2008; pp. 1-3.

53. Gu, J.; Braasch, H.; Burgermeister, W.; Zhang, J. Records of Bursaphelenchus spp. intercepted in imported packaging wood at Ningbo, China. For. Pathol. 2006, 36, 323-333. [CrossRef]

54. Robinet, C.; Van Opstal, N.; Baker, R.; Roques, A. Applying a spread model to identify the entry points from which the pine wood nematode, the vector of pine wilt disease, would spread most rapidly across Europe. Biol. Invasions 2011, 13, 2981-2995. [CrossRef]

55. PM, E. 9/1 Bursaphelenchus xylophilus and its vectors: Procedures for official control. EPPO Bull. 2018, 48, 503-505.

56. Evans, H.; McNamara, D.; Braasch, H.; Chadoeuf, J.; Magnusson, C. Pest risk analysis (PRA) for the territories of the European Union (as PRA area) on Bursaphelenchus xylophilus and its vectors in the genus Monochamus. EPPO Bull. 1996, 26, 199-249. [CrossRef]

57. Meteo. Available online: https://meteo.gr/ (accessed on 31 December 2021).

58. Futai, K. Pine wood nematode, Bursaphelenchus xylophilus. Annu. Rev. Phytopathol. 2013, 51, 61-83. [CrossRef] [PubMed]

59. Naves, P.; de Sousa, E. Threshold temperatures and degree-day estimates for development of post-dormancy larvae of Monochamus galloprovincialis (Coleoptera: Cerambycidae). J. Pest Sci. 2009, 82, 1-6. [CrossRef]

60. Sousa, E.; Bravo, M.A.; Pires, J.; Naves, P.; Penas, A.C.; Bonifácio, L.; Mota, M.M. Bursaphelenchus xylophilus (Nematoda; Aphelenchoididae) associated with Monochamus galloprovincialis (Coleoptera; Cerambycidae) in Portugal. Nematology 2001, 3, 89-91. [CrossRef]

61. Koutroumpa, F.A.; Rougon, D.; Bertheau, C.; Lieutier, F.; Roux-Morabito, G. Evolutionary relationships within European Monochamus (Coleoptera: Cerambycidae) highlight the role of altitude in species delineation. Biol. J. Linn. Soc. 2013, 109, 354-376. [CrossRef]

62. Bragard, C.; Dehnen-Schmutz, K.; Di Serio, F.; Gonthier, P.; Jacques, M.A.; Miret, J.A.J.; Justesen, A.F.; MacLeod, A.; Magnusson, C.S.; Navas-Cortes, J.A. Pest categorisation of non-EU Monochamus spp. EFSA J. 2018, 16, e05435. [CrossRef]

63. European Food Safety Authority; Schenk, M.; Loomans, A.; den Nijs, L.; Hoppe, B.; Kinkar, M.; Vos, S. Pest survey card on Bursaphelenchus xylophilus. EFSA Support. Publ. 2020, 17, 1782E. [CrossRef]

64. Li, M.; Li, H.; Sheng, R.-C.; Sun, H.; Sun, S.-H.; Chen, F.-M. The first record of Monochamus saltuarius (Coleoptera; Cerambycidae) as vector of Bursaphelenchus xylophilus and its new potential hosts in China. Insects 2020, 11, 636. [CrossRef]

65. Pimentel, C.S.; Ayres, M.P.; Vallery, E.; Young, C.; Streett, D.A. Geographical variation in seasonality and life history of pine sawyer beetles Monochamus spp: Its relationship with phoresy by the pinewood nematode Bursaphelenchus xylophilus. Agric. For. Entomol. 2014, 16, 196-206. [CrossRef] 
66. Gavrikov, V.L.; Vetrova, V.P. Effects of fir sawyer beetle on spatial structure of Siberian fir stands. In Forest Insect Guilds: Patterns of Interaction with Host Trees; Baranchikov, Y.N., Mattson, W.J., Hain, F.P., Payne, T.L., Eds.; Gen. Tech. Rep. NE-153; US Department of Agriculture, Forest Service, Northeastern Forest Experiment Station: Radnor, PA, USA, 1991.

67. Togashi, K. Vector-nematode relationships and epidemiology in pine wilt disease. In Pine Wilt Disease; Zhao, B.G., Futai, K., Sutherland, J.R., Takeuchi, Y., Eds.; Springer: Tokyo, Japan, 2008; pp. 162-183.

68. Michalopoulos-Skarmoutsos, H.; Skarmoutsos, G.; Kalapanida, M.; Karageorgos, A. Surveying and recording of nematodes of the genus Bursaphelenchus in conifer forests in Greece and pathogenicity of the most important species. In The Pinewood Nematode, Bursaphelenchus xylophilus, Proceedings of the International Workshop, Évora, Portugal, 20-22 August 2001; Mota, M., Vieira, P., Eds.; Brill Academic Publishers: Leiden, The Netherlands, 2004; pp. 113-126.

69. Lange, C.; Burgermeister, W.; Metge, K.; Braasch, H. Molecular Characterization of Isolates of the Bursaphelenchus sexdentati Group Using Ribosomal DNA Sequences and ITS-RFLP. In Pine Wilt Disease: A Worldwide Threat to Forest Ecosystems, 1st ed.; Mota, M., Vieira, P., Eds.; Springer: Dordrecht, The Netherlands, 2008; pp. 165-173. [CrossRef]

70. Braasch, H. Bursaphelenchus species in conifers in Europe: Distribution and morphological relationships. Bull. OEPP/EPPO Bull. 2001, 31, 127-142. [CrossRef]

71. D’Errico, G.; Carletti, B.; Schröder, T.; Mota, M.; Vieira, P.; Roversi, P.F. An update on the occurrence of nematodes belonging to the genus Bursaphelenchus in the Mediterranean area. Forestry 2015, 88, 509-520. [CrossRef]

72. Torrini, G.; Paoli, F.; Mazza, G.; Simoncini, S.; Strangi, A.; Guidotti, A.; Mori, E.; Roversi, P.F.; Marianelli, L. First detection of Bursaphelenchus abietinus and B. andrassyi in Italy. For. Pathol. 2020, 50, e12627. [CrossRef]

73. Akbulut, S.; Braasch, H.; Cebeci, H. First report of Bursaphelenchus hellenicus Skarmoutsos, Braasch, Michalopoulou (Nematoda: Aphelenchoididae) from Turkey. For. Pathol. 2013, 43, 402-406. [CrossRef]

74. Skarmoutsos, G.; Braasch, H.; Michalopoulou, H. Bursaphelenchus hellenicus sp. n. (Nematoda, Aphelenchoididae) from Greek pine wood. Nematologica 1998, 44, 623-629. [CrossRef]

75. Polomski, J.; Rigling, D. Effect of watering regime on disease development in Pinus sylvestris seedlings inoculated with Bursaphelenchus vallesianus and B. mucronatus. Plant Dis. 2010, 94, 1055-1061. [CrossRef]

76. Akbulut, S.; Yüksel, B.; Serin, M.; Erdem, M. Comparison of pathogenic potential of Bursaphelenchus species on conifer seedlings between greenhouse and outdoor conditions. Phytoparasitica 2015, 43, 209-214. [CrossRef]

77. Öztürk, N.; Akbulut, S.; Baysal, İ. Determination of pathogenicity of Bursaphelenchus species on different pine species under natural conditions in Düzce. Phytoparasitica 2019, 47, 89-97. [CrossRef]

78. Caroppo, S.; Cavalli, M.; Coniglio, D.; Ambrogioni, L. Pathogenicity studies with various Bursaphelenchus populations on conifer seedlings under controlled and open air conditions. Redia 2000, 83, 61-75.

79. Philis, J.; Braasch, H. Occurrence of Bursaphelenchus leoni (Nematoda, Aphelenchoididae) in Cyprus and its extraction from pine wood. Nematol. Mediterr. 1996, 24, 119-123.

80. Braasch, H.; Philis, J. New records of Bursaphelenchus spp. in Cyprus. Nematol. Mediterr. 2002, 30, 55-57.

81. Akbulut, S.; Vieira, P.; Ryss, A.; Yuksel, B.; Keten, A.; Mota, M.; Valadas, V. Preliminary survey of the pinewood nematode in Turkey. Bull. OEPP/EPPO Bull. 2006, 36, 538-542. [CrossRef]

82. Akbulut, S.; Braasch, H.; Baysal, İ.; Brandstetter, M.; Burgermeister, W. Description of Bursaphelenchus anamurius sp. n. (Nematoda: Parasitaphelenchidae) from Pinus brutia in Turkey. Nematology 2007, 9, 859-867. [CrossRef]

83. Akbulut, S.; Vieira, P.; Ryss, A.; Valadas, V.; Keten, A.; Mota, M. Bursaphelenchus Fuchs, 1937 (Nematoda: Parasitaphelenchidae) species associated with Pinus species in northern Turkey. Helminthologia 2008, 45, 89-95. [CrossRef]

84. Akbulut, S.; Elekçioğlu, I.H.; Keten, A. First record of Bursaphelenchus vallesianus Braasch, Schönfeld, Polomski, and Burgermeister in Turkey. Turk. J. Agric. For. 2008, 32, 273-279.

85. Ambrogioni, L.; Palmisano, A.M. Description of Bursaphelenchus tusciae sp. n. from Pinus pinea in Italy. Nematol. Mediterr. 1998, 26, 243-254.

86. Carletti, B.; Irdani, T.; Cosi, E.; Brandstetter, M.; Pennacchio, F.; Roversi, P.F.; Ambrogioni, L. First record of Bursaphelenchus fraudulentus Rühm (Goodey) (Nematoda Aphelenchoididae) in Italy. Redia 2006, 88, 27-35.

87. Carletti, B.; Ambrogioni, L.; Irdani, T.; Brandstetter, M.; Puleri, F.; Surico, F.; Pennacchio, F.; Roversi, P. Morphometrics and molecular identification of some Italian populations of Bursaphelenchus eremus Rühm (Goodey) associated with Quercus spp. Redia 2007, 90, 3-21.

88. Torrini, G.; Strangi, A.; Simoncini, S.; Luppino, M.; Roversi, P.F.; Marianelli, L. First report of Bursaphelenchus fungivorus (Nematoda: Aphelenchida) in Italy and an overview of nematodes associated with Crocus sativus L. J. Nematol. 2020, 52, e2020-23. [CrossRef]

89. Caroppo, S.; Ambrogioni, L.; Cavalli, M.; Coniglio, D. Occurrence of the pine wood nematodes, Bursaphelenchus spp., and their possible vectors in Italy. Nematol. Mediter.r 1998, 26, 87-92.

90. Penas, A.C.; Bravo, M.A.; Naves, P.; Bonifácio, L.; Sousa, E.; Mota, M. Species of Bursaphelenchus Fuchs, 1937 (Nematoda: Parasitaphelenchidae) and other nematode genera associated with insects from Pinus pinaster in Portugal. Ann. Appl. Biol. 2006, 148, 121-131. [CrossRef]

91. Robertson, L.; García-Álvarez, A.; Arcos, S.C.; Díez-Rojo, M.; Mansilla, J.P.; Sanz, R.; Martínez, C.; Escuer, M.; Castresana, L.; Notario, A. Potential insect vectors of Bursaphelenchus spp. (Nematoda: Parasitaphelenchidae) in Spanish pine forests. In Pine Wilt Disease: A Worldwide Threat to Forest Ecosystems, 1st ed.; Mota, M., Vieira, P., Eds.; Springer: Dordrecht, The Netherlands, 2008, pp. 221-234. 
92. Polyanina, K.; Mandelshtam, M.Y.; Ryss, A.Y. Brief review of the associations of xylobiont nematodes with bark beetles (Coleoptera, Curculionidae: Scolytinae). Entomol. Rev. 2019, 99, 598-614. [CrossRef]

93. Dayi, M.; Akbulut, S. Survey for the detection of Bursaphelenchus insect-vector species in the western part of Turkey. Kast. Univ. J. For. Fac. 2018, 18, 215-224. [CrossRef]

94. Sousa, E.; Naves, P.; Bonifácio, L.; Bravo, M.; Penas, A.; Pires, J.; Serrao, M. Preliminary survey for insects associated with Bursaphelenchus xylophilus in Portugal. EPPO Bull. 2002, 32, 499-502. [CrossRef]

95. Andreieva, O.; Korma, O.; Zhytova, O.; Martynchuk, I.; Vyshnevskyi, A. Beetles and nematodes associated with wither Scots pines. Cent. Eur. For. J. 2020, 66, 49-59. [CrossRef]

96. Polomski, J.; Schönfeld, U.; Braasch, H.; Dobbertin, M.; Burgermeister, W.; Rigling, D. Occurrence of Bursaphelenchus species in declining Pinus sylvestris in a dry Alpine valley in Switzerland. For. Pathol. 2006, 36, 110-118. [CrossRef]

97. Mamiya, Y. Initial pathological changes and disease development in pine trees induced by the pine wood nematode, Bursaphelenchus xylophilus. Jpn. J. Phytopathol. 1985, 51, 546-555. [CrossRef]

98. Kuroda, K.; Yamada, T.; Mineo, K.; Tamura, H. Effects of cavitation on the development of pine wilt disease caused by Bursaphelenchus xylophilus. Jpn. J. Phytopathol. 1988, 54, 606-615. [CrossRef]

99. Kiyohara, T.; Suzuki, K. Nematode population growth and disease development in the pine wilting disease. Eur. J. For. Pathol. 1978, 8, 285-292. [CrossRef]

100. Zhao, L.; Jiang, P.; Humble, L.M.; Sun, J. Within-tree distribution and attractant sampling of propagative pinewood nematode, Bursaphelenchus xylophilus: An early diagnosis approach. For. Ecol. Manag. 2009, 258, 1932-1937. [CrossRef]

101. Nakabayashi, Y.; Aikawa, T.; Matsushita, M.; Hoshizaki, K. Sampling design for efficient detection of pine wood nematode, Bursaphelenchus xylophilus, in diseased trees using a DNA detection kit: Variation across branch, trunk and tree. Nematology 2018, 20, 641-652. [CrossRef]

102. Ferris, H.; Bongers, T.; de Goede, R.G. A framework for soil food web diagnostics: Extension of the nematode faunal analysis concept. Appl. Soil Ecol. 2001, 18, 13-29. [CrossRef]

103. Moll, J.; Roy, F.; Bässler, C.; Heilmann-Clausen, J.; Hofrichter, M.; Kellner, H.; Krabel, D.; Schmidt, J.H.; Buscot, F.; Hoppe, B First Evidence That Nematode Communities in Deadwood Are Related to Tree Species Identity and to Co-Occurring Fungi and Prokaryotes. Microorganisms 2021, 9, 1454. [CrossRef] [PubMed]

104. Welch, H. Entomophilic nematodes. Annu. Rev. Entomol. 1965, 10, 275-302. [CrossRef]

105. Poinar, G.O., Jr. Nematodes as facultative parasites of insects. Annu. Rev. Entomol. 1972, 17, 103-122. [CrossRef]

106. Adams, B.; Nguyen, K. Nematode parasites of insects. In Encyclopedia of Entomology; Capinera, J.L., Ed.; Springer: Dordrecht, The Netherlands, 2008; pp. 2577-2584. [CrossRef]

107. Grucmanová, Š.; Holuša, J. Nematodes associated with bark beetles, with focus on the genus Ips (Coleoptera: Scolytinae) in Central Europe. Acta Zool. Bulg. 2013, 65, 547-556.

108. Prospero, S.; Polomski, J.; Rigling, D. Occurrence and ITS diversity of wood-associated Bursaphelenchus nematodes in Scots pine forests in Switzerland. Plant Pathol. 2015, 64, 1190-1197. [CrossRef]

109. Đođ, N.; Cota, E.; Pernek, M. Wood nematode species spectrum in the Mediterranean pine forests of Croatia. Period. Biol. 2015, 117, 505-512. [CrossRef]

110. $\mathrm{Wu}, \mathrm{J} . ;$ Chen, H.; Zhang, Y. Latitudinal variation in nematode diversity and ecological roles along the Chinese coast. Ecol. Evol. 2016, 6, 8018-8027. [CrossRef]

111. Nielsen, U.N.; Ayres, E.; Wall, D.H.; Li, G.; Bardgett, R.D.; Wu, T.; Garey, J.R. Global-scale patterns of assemblage structure of soil nematodes in relation to climate and ecosystem properties. Glob. Ecol. Biogeogr. 2014, 23, 968-978. [CrossRef]

112. Da Silva, J.V.L.; Hirschfeld, M.N.C.; Cares, J.E.; Esteves, A.M. Land use, soil properties and climate variables influence the nematode communities in the Caatinga dry forest. Appl. Soil Ecol. 2020, 150, 103474. [CrossRef]

113. Fitoussi, N.; Pen-Mouratov, S.; Steinberger, Y. Soil free-living nematodes as bio-indicators for assaying the invasive effect of the alien plant Heterotheca subaxillaris in a coastal dune ecosystem. Appl. Soil Ecol. 2016, 102, 1-9. [CrossRef]

114. Ikegami, M.; Jenkins, T.A. Estimate global risks of a forest disease under current and future climates using species distribution model and simple thermal model-Pine Wilt disease as a model case. For. Ecol. Manag. 2018, 409, 343-352. [CrossRef] 